\title{
Kemampuan Menulis Teks Cerpen Mahasiswa Program Sarjana Pendidikan Bahasa Indonesia
}

\author{
Agus Joko Purwadi \\ (corresponding author) \\ Program Studi Pendidikan Bahasa Indonesia, FKIP Universitas Bengkulu, Indonesia \\ Email: agusjokop2808@unib.ac.id

\section{Didi Yulistio} \\ Program Studi Pendidikan Bahasa Indonesia, FKIP Universitas Bengkulu, Indonesia \\ Email: yulistiodidi@unib.ac.id
}

\begin{abstract}
APA Citation: Purwadi, A. J. \& Yulistio, D. (2021). Kemampuan menulis teks cerpen mahasiswa program sarjana pendidikan bahasa Indonesia. Silampari Bisa: Jurnal Penelitian Pendidikan Bahasa Indonesia, Daerah, dan Asing, 4(1), 60-79. https://doi.org/10.31540/silamparibisa.v4i1.1254
\end{abstract}

\begin{abstract}
Abstrak
Tujuan penelitian ini untuk mendeskripsikan kemampuan menulis teks cerita pendek mahasiswa Prodi S-1 Pendidikan Bahasa Indonesia, FKIP Universitas Bengkulu. Ruang lingkup penelitian ini mencakup aspek (1) relevansi isi dengan tema, (2) struktur teks, (3) pilihan kata (diksi), (4) kalimat bergaya bahasa naratif, dan (5) mekanik. Penelitian ini menggunakan metode deskriptif dan pendekatan kuantitatif sederhana. Pengumpulan data menggunakan teknik tes menulis teks cerpen. Sampel penelitian menggunakan teknik purposive sampling, yakni mahasiswa semester 5C Prodi S-1 Pendidikan Bahasa Indonesia, Jurusan Pendidikan Bahasa dan Seni, FKIP Universitas Bengkulu sebanyak 33 orang. Analisis data menggunakan rumus rerata dan analisis akhir secara kualitatif. Hasil penelitian menunjukkan bahwa kemampuan menulis teks cerpen mahasiswa S-1 Pendidikan Bahasa Indonesia FKIP Universitas Bengkulu berkategori baik (rerata skor 81,68). Artinya, mahasiswa telah memiliki kemampuan yang memadai dalam menulis cerpen walaupun masih perlu ditingkatkan lagi agar mencapai hasil maksimal. Secara khusus, emapat aspek kemampuan menulis teks cerpen sudah dicapai dengan kategori baik, yakni aspek (1) kesesuaian tema dengan isi, (2) struktur teks, (3) ketepatan diksi atau pilihan kata, dan (4) aspek mekanik atau ejaan bahasa Indonesia, serta (5) aspek kalimat bergaya bahasa naratif berkategori sangat baik. Adapun sumbangan setiap aspek terhadap kemampuan menulis teks cerpen mahasiswa, yakni sumbangan aspek: (a) struktur sebesar 29,26\%, (b) kalimat bergaya naratif sebesar 21,33\%, (c) relevansi tema dengan isi sebesar 20,14\%, (d) diksi atau pilihan kata sebesar 19,81\%, dan (e) mekanik sebesar 9,45\%. Adapun, sumbangan tertinggi diperoleh dari aspek struktur teks.
\end{abstract}

Kata kunci: kemampuan, menulis, teks, cerpen 
Agus Joko Purwadi, Didi Yulistio

Kemampuan Menulis Teks Cerpen Mahasiswa Program Sarjana Pendidikan Bahasa Indonesia

\title{
Ability to Write Short Stories for Undergraduate Students in Indonesian Language Education
}

\begin{abstract}
The purpose of this study was to describe the ability to write short story texts for students of the Indonesian Language Education Study Program, Faculty of Teacher Training and Education, Bengkulu University. The scope of this research covers aspects of (1) the relevance of the content to the theme, (2) the structure of the text, (3) the choice of words (diction), (4) narrative style sentences, and (5) mechanics. This study uses a descriptive method and a simple quantitative approach. The data collection used a short story writing test technique. The research sample used a purposive sampling technique, namely 33 students in the 5C semester of S-1 Indonesian Language Education Study Program, Department of Language and Arts Education, FKIP Bengkulu University. Data analysis used the mean formula and qualitative final analysis. The results of the study showed that the ability to write short stories for undergraduate students of Indonesian Language Education FKIP Bengkulu University was categorized as good (mean score 81.68). That is, students already have adequate skills in writing short stories although they still need to be improved in order to achieve maximum results. In particular, the ability to write short stories in four aspects has been achieved in good categories, namely (1) the suitability of the theme with the content, (2) the structure of the text, (3) the accuracy of word choice of diction, and (4) the mechanical aspects or spelling of Indonesian, and (5) aspects of narrative style sentences are categorized as very good. As for the contribution of each aspect to students' short story writing skills, namely the contribution of aspects (a) structure of $29.26 \%$, (b) narrative style sentences of $21.33 \%$, (c) relevance of theme to content of $20.14 \%$, (d) diction or word choice by $19.81 \%$, and (e) mechanics by $9.45 \%$. Meanwhile, the highest contribution was obtained from the aspect of the structure of the text.
\end{abstract}

Keywords: ability, writing, text, short story

\section{A. Pendahuluan}

Keberhasilan proses pembelajaran di sekolah salah satu faktornya terletak pada kualitas guru yang mengajar di kelas. Bidang studi bahasa Indonesia yang dikelola oleh guru bahasa Indonesia perlu guru berkualitas. Kualifikasi guru bahasa Indonesia yang berkualitas tentu bermuara atau diawali dari proses pendidikan yang dilakukan di lembaga pendidikan tenaga kependidikan, dalam hal ini FKIP. Pendidikan guru harus sudah tidak lagi mengedepankan "cetak guru", tetapi perlu mencetak pendidik yang memiliki kompetensi pendidik sesuai tuntutan UU Nomor 14 tahun 2005 tentang Guru dan Dosen terutama yang berkaitan dengan profesionalisme guru. Menurut undang-undang ini bahwa guru adalah pendidik profesional yang memiliki kompetensi (kompetensi pedagogik, kompetensi kepribadian, kompetensi sosial, dan kompetensi profesional). Oleh karena itu, perguruan tinggi dalam hal ini LPTK atau FKIP perlu melahirkan pendidik yang berkualitas dalam penguasaan bidang ilmu dan memiliki ilmu mendidik atau berkompetensi pedagogik dan profesional sedangkan kompetensi kepribadian dan sosial diharapkan akan dengan sendirinya dimiliki oleh setiap guru sebagai karakter dan kepribadian pendidik yang mempersiapkan anak bangsa berkualitas.

Mahasiswa calon guru harus mampu menyiapkan dan membekali dirinya untuk mandiri serta secara terus-menerus meningkatkan kemampuan dasar yang perlu dimilikinya sebagai pendidik, seperti dalam mengelola kurikulum pendidikan sesuai bidang studinya dan menguasai bidang keilmuan bahasa Indonesia (keterampilan berbahasa, pengajaran bahasa, kebahasaan dan kesastraan). Mahasiswa calon guru bahasa Indonesia harus mengerti hal apa yang akan diajarkan dan cara mengajarkannya. Cooper (dalam Satori, 2009) menegaskan bahwa kemampuan dasar profesi guru ini, paling tidak mencakup empat komponen, yakni (1) memiliki pengetahuan tentang konsep 
dan praktik belajar dan mengajar (teaching and learning) serta sarana pendukungnya, (2) memiliki pengetahuan terhadap bidang keilmuan yang diampu, (3) memiliki keterampilan menyampaikan materi sesuai bidang ilmunya secara baik, dan (3) memiliki sikap dan perilaku serta sifat yang tepat terhadap diri sendiri, teman sejawat atau orang lain, dan bidang keilmuannya serta lembaga tempatnya bernaung atau bereksistensi. Oleh karena itu, mereka perlu mempelajari berbagai garis besar materi pelajaran, tujuan pembelajaran yang harus dicapai di sekolah nantinya sesuai dengan kurikulum yang berlaku. Calon guru bahasa Indonesia perlu mempelajari kurikulum 2013 bidang studi bahasa Indonesia sehingga nanti ketika terjun ke sekolah berhadapan dengan siswanya dapat menguraikan dan menjabarkan berbagai materi pelajaran sesuai kurikulum 2013 yang dimaksud. Untuk dapat mengajarkan materi pelajaran perlu memperdalam pengetahuan dan keterampilannya, khususnya dalam memahami materi pelajaran dan memiliki kemampuan mengajarkan. Seperti materi pembelajaran keterampilan menulis teks perlu dikuasai ketika mengikuti perkuliahan menulis. Kesiapan dan penguasaan materi ketika dalam perkuliahan sangat perlu dilakukan sehingga ketika sudah harus menerapkan di sekolah tidak ragu dan bahkan akan memantapkan pemilikan keyakinan dari segi pengetahuan dan penguasaan keilmuan sesuai bidang studinya.

Pembelajaran bahasa Indonesia sesuai kurikulum 2013 berbasis teks. Artinya, kegiatan pembelajaran mengacu pada penguasaan teks dengan tuntutan capaiannya, yakni kemampuan menulis teks sesuai jenisnya, seperti menulis teks laporan hasil observasi, deskripsi, eksposisi, eksplanasi, prosedur, biografi, dan lainnya sesuai tingkat pendidikan. Pembelajaran berbasis teks ini dimaksudkan untuk mencapai kemampuan tinggi dalam penguasaan penggunaan struktur bahasa. Hal ini mengingat tingkat literasi (berpikir) siswa kita secara nasional, yakni hasil persentase pencapaian level PISA bahasa tahun 2012, rata-rata hanya berada pada level 3 sementara negara lain di Asia Tenggara sudah di atasnya (lihat hasil PISA 2009; 2012). Disamping itu, hasil capaian siswa yang belum membanggakan pada UN bahasa Indonesia berbasis KTSP dan hasil studi organisasi internasional, seperti TIMMS, bahwa sebagian besar siswa Indonesia hanya mampu menjawab persoalan pada level menengah (sebanyak 95\%) sedangkan kemampuan siswa dalam menjawab soal yang memerlukan pemikiran masih sangat rendah, hanya 5\% (Kementerian Pendidikan dan Kebudayaan RI, 2013: 2). Oleh karena itu, tingkat literasi anak harus dilakukan pembinaan sebagai upaya menumbuhkan kompetensi dan performansi melalui budaya menulis, khususnya mengembangkan halhal apa yang dilihat, didengar, dan dipikirkan sehingga memungkinkan memunculkan ideide kritis-kreatif yang dapat dikembangkan ke dalam bentuk literasi anak didik yang lebih tinggi.

Kualitas literasi (berpikir) siswa yang rendah tidak dapat dipungkiri bahwa itu sebagai dampak dari model pembelajaran bahasa Indonesia yang dibina oleh guru. Untuk itu, pengembangan kemahiran berbahasa Indonesia melalui kemampuan menulis teks perlu dilakukan. Pengembangan kemampuan menulis berbasis teks adalah salah satu upaya membina dan mengembangkan pola berpikir peserta didik secara cepat, runtut, kritis, dan kreatif. Kompetensi menulis berbasis teks ini terlebih dahulu harus dimiliki oleh mahasiswa calon guru bidang studi bahasa Indonesia sebagai pengarah dalam pembelajaran. Pencapaian kompetensi menulis (teks) sesuai kurikulum 2013 sudah dicanangkan sejak sekolah dasar. Pada tingkat ini, siswa telah dituntut untuk menulis kalimat dengan gagasan sederhana dalam urutan yang jelas dan menggunakan kata-kata sendiri. Selain itu, sesuai standar kompetensi lulusan bidang studi bahasa Indonesia, bahwa orientasi menulis berkenaan dengan menulis efektif berbagai jenis teks dalam berbagai konteks dan tujuan untuk mencapai pembelajaran komunikatif (Bachman, 1990: 85). Dalam pembelajaran keterampilan menulis harus berisi kompetensi kaidah 
kebahasaan yang memadai dan kepekaan kontekstual yang tinggi. Sebab, menulis yang sederhana sekalipun tidak mungkin dapat terwujud tanpa pengetahuan tentang kaidah bahasa yang juga sederhana. Namun, kenyataan menunjukkan, hasil pembelajaran keterampilan menulis siswa masih jauh dari harapan. Masih banyak siswa sekolah menengah pertama yang kurang mampu menuangkan gagasan ke dalam tulisan secara baik, walaupun mereka telah mengikuti pelajaran bahasa Indonesia, termasuk menulis sejak sekolah dasar.

Pengamatan peneliti terhadap pelaksanaan pembelajaran bahasa Indonesia, bahwa upaya melatih siswa menulis selama ini lebih banyak dimulai setelah penjelasan tentang menulis berakhir. Akibatnya, pembelajaran menulis menjadi sebuah penjelasan teori yang panjang dan praktik menulis menjadi jarang dilakukan atau jika dilakukan menjadi tugas/pekerjaan rumah karena jam pelajaran telah usai. Dampak pembelajaran menulis yang dikerjakan di rumah, bahwa hasil pembelajaran siswa menjadi tidak bermakna dan kurang efektif karena proses penuangan ide ke dalam teks tidak secara langsung dialami siswa sebagai bagian dari proses pembelajaran "membangun teks secara mandiri" yang dikelola guru dan bahkan hasil menulis tidak dikoreksi bersama-sama sebagai upaya yang 'membelajarkan' siswa dalam membangun teks karena pembelajaran esoknya sudah harus melanjutkan materi berikutnya.

Kegiatan menulis memang bukan hal yang mudah bagi siswa di sekolah. Menurut beberapa guru, kesulitan utama terletak pada kegiatan menuangkan ide pokok atau gagasan ke dalam rangkaian kalimat yang runtut sehingga berwujud tulisan. Tulisan siswa dimungkinkan kurang berkembang dengan baik, karenal ketika mulai menulis, apa yang sudah dipikirkan mengalami kebuntuan. Informasi yang diberikan guru bahwa kecenderungan siswa kurang mampu mengekspresikan gagasan dan keruntutan dalam berpikirnya. Kaitannya dengan implementasi kurikulum 2013, bahwa hambatan muncul kembali ketika mulai menulis berbagai jenis teks dan hal ini pun dialami oleh beberapa guru yang tampak belum siap mengekspresikan proses pembelajaran menulis teks tersebut. Sebab, pemahaman menulis teks ini baru saja diperoleh ketika mengikuti pelatihan kurikulum 2013 yang belum sepenuhnya mengangkat masalah pemahaman dan penguasaannya pada pendekatan teks bidang studi bahasa Indonesia.

Kemampuan menulis teks memerlukan kemahiran tersendiri bagi guru bahasa Indonesia. Untuk itu, mahasiswa calon guru perlu memiliki tidak saja kemahiran dalam penggunaan aspek kebahasaan, tetapi juga kemampuannya dalam menuangkan gagasan pada jenis teks dan bernalar secara runtut serta memahami struktur teks dalam mewujudkan tulisan sekalipun itu teks cerita. Berkaitan dengan mewujudkan tulisan, bahwa bentuk teks cerpen sangat beragam, khususnya menulis cerita pendek bertema fiksi atau nonfiksi. Pembelajaran menulis cerpen saat ini belum mampu membangun kreativitas siswa untuk secara rutin menulis sebagai keterampilan berkarya. Pembelajaran menulis cerpen akan berhasil jika dilakukan dengan menggunakan langkah-langkah pembelajaran yang baik dan mudah diikuti siswa. Cerpen merupakan salah satu bentuk karya sastra. Zainurrahman (2011: 37) mengemukakan bahawa cerpen merupakan sebuah teks narasi yang bersifat fiksi dan menceritakan kejadian dan tikaian (konflik), serta menamkan nilai moral dan menghibur pembacanya. Melalui karya cerpen, penulis dapat menyampaikan isi hatinya disamping berimajinasi dalam peristiwa kehidupan dunia maya dan dunia nyata.

Hasil pengamatan terhadap tugas-tugas yang dibuat mahasiswa Prodi Pendidikan Bahasa Indonesia FKIP Universitas Bengkulu yang berkaitan dengan tugas praktik dasar menulis atau keterampilan fiksional belum sepenuhnya terbekali dengan keterampilan menulis yang baik bahkan masih replikasi bentuk yang ada. Artinya, produk kemampuan menulis teks sesuai aturan yang benar mestinya harus memenuhi aspek seperti isi (kesesuaian tema, judul dengan isi), pilihan kata, kalimat, dan mekanik serta aspek 
struktur teks. Untuk menulis teks cerpen pun perlu mencakup tiga unsur struktur teks, yakni orientasi, komplikasi, dan resolusi yang hal ini juga belum sepenuhnya diwujudkan. Sesuai dengan kurikulum 2013 yang berbasis teks dengan capaian keterampilan menulis teks dengan berbagai jenisnya, baik di SMP maupun SMA sesuai tingkatan pendidikan. Seperti di SMP kelas VII guru perlu mengajarkan 5 jenis teks, yakni (1) teks laporan hasil observasi, (2) teks tanggapan deskripsi, (3) teks eksposisi, (4) teks eksplanasi dan (5) teks cerita pendek (Wiratno, 2014). Begitupun di SMA kelas XI terdapat menulis teks cerpen. Oleh karena itu, pemilikan kemahiran dalam menulis teks ini perlu diupayakan secara baik oleh mahasiswa calon guru bahasa Indonesia dalam Mata Kuliah Keterampilan Dasar Menulis dan/atau dalam Mata Kuliah Keterampilan Menulis Fiksional.

Kenyataan di atas perlu diatasi dan diperkuat berkaitan dengan hasil penelitian Yulistio dan Fithri (2019: 19), bahwa kemampuan menulis teks cerpen siswa SMAN 2 Kota Bengkulu termasuk berkategori sangat baik. Terjadi peningkatan yang konsisten pada peningkatan proses dan hasil pembelajaran menulis cerpen. Proses aktivitas pembelajaran siswa berkategori sangat aktif dalam mendeskripsikan struktur teks, nilainilai kehidupan, dan struktur pembangun cerpen yang dipelajarinya diikuti dengan hasil pembelajaran menulis cerpennya yang juga berkategori sangat baik. Artinya, pembelajaran menulis teks di Prodi Pendidikan Bahasa Indonesia ini juga perlu dipersiapakan secara baik sehingga produk lulusannya akan lebih berkualitas sejalan dengan kenyatakan di lapangan tersebut. Hasil penelitian ini juga sebagai wujud nyata bahwa di tingkat praktis dalam hal ini siswa sekolah menengah atas sudah memiliki bukti kemahiran. Oleh karena itu, mahasiswa calon guru bahasa Indonesia yang kelak akan berhadapan dengan siswa dan menjadi guru di sekolah perlu lebih memperdalam dalam pembelajaran menulis teks agar berdampak pada pencapaian pengetahuan, keterampilan, dan sikapnya. Khususnya dalam mencapai standar kompetensi lulusan sesuai dengan tingkatan pendidikan. Untuk itu, pemilikan kemampuan menulis teks cerpen mahasiswa calon guru bahasa Indonesia sangat penting dan mendesak serta salah satu wujud pemantauan kompetensinya melalui penelitian ini.

Kemampuan menulis merupakan kecakapan seseorang (penulis) dalam merangkai bahasa dan keruntutan pikiran dalam tulisan. Kaitannya dengan kompetensi atau keterampilan, maka menulis merupakan suatu hasil usaha seseorang dalam proses menuangkan buah pikiran ke dalam bahasa tulis melalui kalimat-kalimat yang dirangkai secara lengkap, utuh, dan jelas sehingga dapat dikomunikasikan kepada pembaca secara berhasil. Hal ini sebagaimana Rivers (dalam Hadley, 1993: 290-292) mengemukakan bahwa kemampuan menulis merupakan kecakapan seseorang dalam praktik menulis secara alamiah dengan memanfaatkan konteks nyata. Definisi secara khusus, bahwa kemampuan menulis melibatkan dua hal yakni kemampuan menerima dan menggunakan. Kemampuan yang terarkhir ini berkaitan dengan aktivitas yang menekankan pada penggunaan kode bahasa untuk tujuan mengkomunikasikan gagasan, ide-ide dalam wujud tulisan. Byrne (dalam Yulistio, 2012: 25) menyatakan bahwa keterampilan menulis adalah suatu hasil usaha seseorang dalam mewujudkan dan kolektivitas pengetahuan kebahasaan dan pengolahan gagasan melalui pikiran yang direfleksikan melalui wujud tulisan sehingga dapat dikomunikasikan kepada pembaca secara berhasil. Dengan demikian, dapat dikatakan bahwa kemampuan menulis adalah kecakapan penulis (guru dan siswa) dalam menyampaikan gagasan, ide-ide atau pesan sebagai akumulasi pikiran dan pengalaman dengan menggunakan rangkaian lambang bahasa ke dalam wujud tulisan.

Menulis teks sesuai jenisnya harus mengacu pada konteks dan melibatkan peristiwa atau kejadian nyata sehingga menghasilkan wujud tulisan yang lebih realistis walaupun dalam jenis tertentu, seperti teks prosa fiksi juga dapat ditulis dari hasil bernarasi atau 
berimajinasi. Oleh karena itu, dalam menulis teks lebih tepat bersinergi dengan pendekatan kontekstual. Pendekatan teks dalam menulis teks dengan latar belakang atau objek tulisan nyata akan memungkin penulis dapat mengaplikasikan peristiwa kehidupan yang sebenarnya. Blanchard (dalam Nur, 2001) menyatakan bahwa pembelajaran (termasuk menulis teks) dengan pendekatan kontekstual akan memungkinkan proses dan hasil pembelajaran terjadi dari hubungan yang erat dengan kehidupan sesungguhnya. Latief (2002: 2-4) menegaskan bahwa pembelajaran menulis teks dengan pendekatan kontekstual akan membantu guru dan siswa mengaitkan isi materi pelajaran dengan dunia nyata.

Johnson (2002: 13) menyataan bahwa dalam pembelajaran menulis teks secara kontekstual akan membantu guru dan siswa untuk dapat menemukan makna pelajaran dan kemampuan mengingat. Lebih lanjut, Johnson (2002: 24) menegaskan bahwa komponen pembelajaran kontekstual mencakup delapan hal, yakni (1) pembuatan koneksi yang bermakna (making meaningful connections), (2) melakukan signifikansi pekerjaan (doing signifficant work), (3) belajar untuk mandiri (self regulated learning), (4) bekerja sama (collaborating), (5) berpikir kritis dan kreatif (critical and cerative thinking), (6) mengutamakan kebutuhan individual (nurturing the individual), (7) pencapaian standar tinggi (reaching high standards), dan (8) penggunaan penilaian autentik (using authentic assessment). Ketika, guru dan siswa menemukan makna di dalam pelajaran maka mereka akan melaksanakan proses pembelajaran dengan berliterasi dan mengingat apa yang mereka pelajari. Sehingga melalui teks yang disusun akan teraplikasi hubungan yang jelas antara isi pelajaran, struktur teks, dan komponen pembangun teks secara akademis dengan konteks kehidupan keseharian mereka sebagai suatu pengalaman baru yang bermakna. Dengan demikian, dalam proses pembelajaran guru dan siswa secara bersama-sama dan mandiri akan mendapatkan pengetahuan yang bermakna, terlibat langsung dan berperan aktif dalam menemukan materi yang dipelajari dengan kenyataan, dan dapat menerapkan kembali hasil pembelajaran dalam kehidupan yang sebenarnya. Dengan kata lain, bahwa ketika proses pembelajaran menulis teks sudah dilaksanakan maka personal pembelajaran dalam hal ini guru dan siswa akan dapat mengaktifkan dan memperoleh pengetahuan baru, mampu mempraktikkan pengetahuan dan pengalaman tersebut sebagai wujud keterampilan, dan mampu merefleksi hasil pembelajaran yang telah dicapai sebagai suatu wujud dari sikap dalam berbahasa tulis (menulis teks) secara baik.

Pembelajaran menulis teks di Sekolah berdasarkan kurikulum 2013 sangat bervariasi dengan jenis yang berbeda tiap tingkatan kelas dan pendidikan. Khusus dalam menulis teks cerita pendek, bahwa kegiatan pembelajaran menulis ini dapat diwujudkan melalui kegiatan yang terencana dan terprogram dengan mengaktifkan siswa melalui 4 langkah kegiatan dalam berbahasa, yakni (a) membangun konteks, (b) pemodelan teks, (c) kerja sama membangun teks, dan (d) kerja mandiri membangun teks (Wiratno, 2014). Beberapa jenis teks dapat dibedakan atas dasar tujuan (yang tidak lain yakni fungsi sosial teks), struktur teks (tata organisasi), dan ciri kebahasaan teks tersebut. Sesuai dengan prinsip itu, suatu teks yang berbeda tentu memiliki fungsi yang berbeda, struktur teks berbeda, dan ciri kebahasaan yang berbeda pula. Dengan kata lain, bahwa pembelajaran bahasa Indonesia yang berbasis teks merupakan model pembelajaran yang memungkinkan pembelajar (siswa atau mahasiswa) untuk dapat menguasai dan menggunakan berbagai jenis teks tersebut di masyarakat, termasuk salah satunya teks cerpen.

Kemampuan menulis teks adalah kecakapan seseorang (guru) dalam menuangkan ide-ide, gagasan melalui pikiran yang tersusun logis dengan memanfaatkan kalimatkalimat yang terangkai secara baik dan dituangkan dalam tulisan berwujud teks. Tulisan berwujud teks maksudnya bahwa tulisan yang dihasilkan sebagai produk menulis 
seseorang yang terdiri dari berbagai jenis tulisan (berbagai jenis teks). Kemampuan menulis teks ini tidak dapat datang begitu saja, tetapi memerlukan waktu dan kesempatan. Artinya, apabila ada waktu dan kesempatan yang dimiliki seseorang dapat diprogramkan untuk melakukan menulis teks tersebut. Menulis teks sebagai bagian dari keterampilan dalam berbahasa maka dapat dicapai melalui kegiatan berlatih atau latihan secara rutin hingga tercapai pemilikan keterampilan dalam mewujudkan berbagai jenis teks tertulis. Latihan menulis teks secara terprogram dengan rutinitas yang efektif-efisien dapat dilakukan seseorang (guru dan siswa) melalui pemahaman dan penerapan terhadap unsur bentuk (form) dan fungsi (function) struktur kebahasaan, alur berpikir logis dan runtut, dan struktur tulisan atau struktur teks yang akan ditulis sehingga mampu mengkomunikasikan pesan, ide-ide atau gagasan kepada pembaca secara berhasil.

Kemampuan menulis teks ini dalam proses pembelajaran bahasa Indonesia kurikulum 2013 di sekolah mulai dipelajari di sekolah menengah. Materi pembelajaran menulis dalam bidang studi bahasa Indonesia dilakukan pada pencapaian tujuan menulis teks tersebut. Teks yang ditulis haruslah merupakan satuan bahasa yang memiliki kandungan makna, pikiran, dan gagasan yang lengkap. Hal inilah yang menjadi dasar dalam mencapai materi pembelajaran atau perkuliahan keterampilan dasar menulis atau keterampilan menulis fiksional. Artinya, bahwa segi kandungan materi pembelajaran bahasa Indonesia khususnya menulis, tidak cukup hanya pada tingkat menulis paragraf dengan menggunakan kalimat utama atau kalimat penjelas tertentu dan menemukan tema paragraf dan ide pokoknya saja tetapi harus sampai pada paragraf jenis apa (memiliki kandungan lengkap konsep satuan bahasa) yang akan dikembangkan. Satuan bahasa dengan kandungan makna, pikiran, dan gagasan yang lengkap tidak lain adalah teks, maka pembelajaran bahasa Indonesia sudah selayaknya menerapkan pendekatan teks dengan capaian proses dan hasil pada penguasaan penggunaan bahasa tulis yakni menulis teks dengan berbagai ragam jenisnya, yang salah satunya adalah teks cerpen.

Cerpen merupakan bentuk karya sastra aliran prosa baru yang bersifat fiksi. Prosa merupakan karangan fiksi yang diartikan sebagai rekaan. Oleh karena itu, prosa fiksi yang salah satunya berbentuk cerpen sebagai karya rekaan yang tokoh, peristiwa, dan latarnya digambarkan secara imajinatif atau bersifat khayalan. Sudjiman (1990:17) mengemukakan bahwa prosa fiksi sebagai karya rekaan, diartikan sebagai kisah yang mempunyai tokoh, lakuan, dan alur yang dihasilkan oleh daya khayal atau imajinasi. Cerita pendek (cerpen) adalah suatu bentuk prosa baru berbentuk cerita atau naratif fiktif yang tidak ada aturan baku tentang panjang pendeknya tulisan. Dalam hal ini Edgar Allan Poe (dalam Nurgiyantoro, 1995:11) menyatakan bahwa cerita pendek merupakan sebuah cerita yang selesai dibaca sekali duduk, kira-kira berkisar antara setengah jam sampai dua jam. Beberapa ahli mendeskripsikan dari segi jumlah kata minimal 5000 kata atau kira-kira 17 halaman kuarto dengan spasi rangkap (Notosusanto dalam Tarigan, 2013).

Cerita pendek, selain kependekannya ditunjukkan oleh jumlah penggunaan kata yang relatif terbatas, peristiwa dan isi cerita yang disajikan juga sangat pendek dengan tujuan membangkitkan suatu efek perasaan dalam diri pembaca (Noermanzah, 2017:29). Peristiwa yang disajikan memang singkat, tetapi mengandung kesan yang dalam. Isi cerita memang pendek karena mengutamakan kepadatan ide dan langsung pada tujuannya. Karena itu, peristiwa dan isi cerita dalam cerpen relatif lebih sedikit jika dibandingkan dengan roman atau novel. Karena singkatnya, cerita-cerita pendek yang sukses mengandalkan teknik-teknik sastra, seperti tokoh, plot, tema, bahasa, dan insight, secara lebih luas dibandingkan dengan fiksi lain yang lebih panjang. Disyaratkan oleh H.B. Jassin bahwa cerita pendek haruslah memiliki bagian perkenalan, pertikaian, dan penyelesaian (Rampan, 1995:10). Berdasarkan berbagai batasan dan ciri cerita pendek di atas, dapat disimpulkan bahwa cerita pendek adalah bentuk prosa fiktif naratif yang habis 
dibaca sekali duduk, serta mengandung konflik dramatik. Cerita pendek adalah cerita fiksi bentuk prosa yang singkat yang unsur ceritanya berpusat pada satu peristiwa pokok sehingga jumlah dan pengembangan pelaku terbatas, dan keseluruhan cerita memberi kesan tunggal. Hal struktur teks inilah yang ditandai dengan bentuk susunan isi dalam paragraf-paragraf yang masing-masing berisi sebagaimana ditegaskan Jassin di atas.

Teks cerita pendek (cerpen) mempunyai fungsi sosial menyampaikan peristiwa kehidupan yang bernilai dari suatu fiksional. Dengan klasifikasi, hal yang dilaporkan itu dapat digolongkan ke dalam kelas atau subkelas tertentu, seperti penjelasan umum, deskripsi bagian-bagian dan deskripsi manfaat sebagaimana struktur teks laporan hasil observasi. Berkaitan dengan komponen organisasi atau struktur teks bahwa teks adalah satuan bahasa terlengkap dengan kandungan makna, pikiran, dan gagasan. Dalam pengelompokkannya, teks dapat berwujud teks tulis dan teks lisan. Dalam menulis teks diperlukan organisasi atau struktur teks tersebut. Struktur teks yang baik akan membentuk struktur/pola berpikir yang baik pula sehingga setiap penguasaan jenis teks tertentu (oleh mahasiswa) akan memiliki keruntutan kemampuan berpikir sesuai dengan jenis teks yang ditulisnya (Kementerian Pendidikan dan Kebudayaan RI, 2013: 3). Untuk itu, mahasiswa sebagai calon guru bahasa Indonesia harus lebih dahulu mengetahui kelima jenis teks tersebut. Salah satu jenis teks tersebut yakni teks cerita pendek. Hal ini sangat penting dikuasai karena mahasiswa Pendidikan bahasa Indonesia dalam perkuliahan tidak terlepas dari tugas membuat (menulis) fiksi (seperti menulis puisi, prosa; cerpen atau novel) dan nonfiksi atau karya ilmiah termasuk kajian prosa cerpen. Kementerian Pendidikan dan Kebudayaan RI (2014:49-50) dan Wiratno (2014) mendeskripsikan berbagai jenis teks dengan struktur teks yang berbeda-beda sesuai kedalaman bentuk dan fungsinya. Jenis teks cerita pendek, dengan unsur struktur teks mencakup: (a) orientasi, (b) komplikasi, dan (c) resolusi. Struktur teks ini menjadi dasar penilaian, sebagai salah satu komponen yang memiliki bobot 30 untuk menilai ketepatan strukturnya. Dalam membangun teks yang perlu dipahami bahwa struktur teks cerita pendek terdiri atas bagian: (a) orientasi merupakan bagian pembuka tulisan yang bersifat umum menyampaikan peristiwa apa yang terjadi, (b) komplikasi merupakan bagian isi yang mengakibatkan pertikaian antartokohnya, dan (c) resolusi merupakan bagian akhir atau penyelesaian dari konflik yang terjadi.

Komponen dalam menilai kualitas teks, dapat dilakukan dengan berbagai prosedur. Perkins (dalam Hadley, 1993: 343-345) mengemukakan prosedur yang dapat digunakan untuk menilai tulisan, mencakup (1) penilaian holistik, yakni prosedur penilaian tulisan yang digunakan untuk menilai kecakapan secara menyeluruh dan langsung pada tulisan dengan menekankan pada sistem komunikas-nya, (2) penilaian analitik adalah prosedur menilai tulisan secara terpisah-pisah berdasarkan komponen menulis yang dirujuk, (3) penilaian primer adalah prosedur dalam menilai tulisan menurut unsur atau ciri-ciri dasar suatu tulisan, seperti aspek organisasi, kosa kata, dan komponen strukturnya. Heaton (1988:147) mengemukakan bahwa penilaian tulisan lebih baik dilakukan melalui metode penilaian analitik dengan jumlah penilai lebih dari satu penilai. Hal ini, dimaksudkan untuk mendapatkan hasil penilaian yang lebih objektif. Dengan menggunakan penilaian secara analitik berarti hasil menulis pembelajar akan dinilai menurut komponen menulis yang telah ditentukan secara rinci. Model penilaian menulis teks secara analitik menurut Jacobs dkk. (1981: 30-31) mencakup lima komponen, yakni (1) isi, (2) struktur atau organisasi tulisan, (3) kosakata, (4) penggunaan kalimat, dan (5) mekanik dan tulisan tangan dengan bobot skor masing-masing komponen bervariasi sesuai kebutuhan. Berdasarkan komponen kemampuan menulis teks di atas maka dalam penelitian ini menggunakan prosedur penilaian analitik, khususnya menulis teks cerpen mencakup komponen atau aspek isi, struktur teks, pilihan kata, penggunaan kalimat naratif, dan mekanik. 
Agus Joko Purwadi, Didi Yulistio

Kemampuan Menulis Teks Cerpen Mahasiswa Program Sarjana Pendidikan Bahasa Indonesia

\section{B. Metodologi Penelitian}

Penelitian ini menggunakan pendekatan kuantitatif melalui statistik deskriptif atau statistik sederhana dan metode deskriptif. Metode deskriptif dimaksudkan sebagai cara dalam mendeskripsikan data kemampuan menulis teks cerpen mahasiswa Prodi Pendidikan Bahasa Indonesia FKIP Universitas Bengkulu. Pelaksanaan penelitian dilakukan di Prodi S-1 Pendidikan Bahasa Indonesia FKIP Universitas Bengkulu, Jalan W.R. Supratman Kandang Limun Bengkulu. Waktu penelitian dilaksanakan pada Semester Ganjil 2019/2020, yakni bulan September dan Oktober 2019. Data penelitian ini berupa tulisan atau teks cerpen mahasiswa dari sebanyak 33 judul tulisan dengan tema "Kehidupan Kampus".

Populasi penelitian ini adalah seluruh mahasiswa semester $\mathrm{V}$ Prodi Pendidikan Bahasa Indonesia FKIP Universitas Bengkulu, berjumlah 112 orang. Sampel penelitian, menggunakan teknik sampel bertujuan (purposive sampling), yakni pengambilan sampel berdasarkan tujuan tertentu (Sevilla dkk., 1993). Dalam hal ini diambil mahasiswa semester 5C berjumlah 33 orang. Pengumpulan data dalam penelitian ini menggunakan teknik tes, yakni meminta mahasiswa menulis teks cerpen dengan ketentuan dan petunjuk menulis yang ditentukan seperti memperhatikan 5 komponen dan tema.

Instrumen yang digunakan yaitu tes menulis teks cerpen mencakup petunjuk menulis cerpen, kisi-kisi komponen menulis cerpen, dan profil penilaian kemampuan menulis teks cerpen yang didasarkan pada 5 aspek dan bobot nilai bervariasi mencakup isi (bobot 20), struktur teks (bobot 30), pilihan kata (bobot 20), penggunaan kalimat naratif (bobot 20), dan mekanik (bobot 10). Aspek struktur teks mencakup 3 unsur, yakni orientasi, komplikasi, dan resolusi. Analisis data utama penelitian dilakukan secara kuantitatif menggunakan statistik deskriptif dengan menentukan nilai rerata (Djiwandono, 2008) dan hasil hitung rerata dikonfirmasikan secara kualitatif untuk menentukan kemampuan menulis teks cerita pendek mahasiswa.

\section{Hasil Penelitian dan Pembahasan \\ 1. Hasil Penelitian}

Deskripsi data kemampuan menulis teks cerita pendek mahasiswa kelas $5 \mathrm{C}$ Prodi S-1 Pendidikan Bahasa Indonesia FKIP Universitas Bengkulu, Semester Ganjil Tahun Akademik 2019/2020 dengan tema "Kehidupan Kampus" dan topik/judul tulisan bebas diperoleh dari sumber tulisan sebanyak 33 orang mahasiswa. Penelitian dengan teknik tes menulis teks cerita pendek (cerpen) dilaksanakan pada hari Senin, 7 Oktober 2019, Pukul 8.00 s.d 10.00 WIB. Deskripsi data penelitian didasarkan pada 5 (lima) aspek, mencakup: (1) kesesuaian judul dengan isi, (2) struktur teks meliputi orientasi, komplikasi, dan resolusi, (3) diksi atau pilihan kata, (4) penggunaan kalimat naratif, dan (5) mekanik (ejaan dan tulisan tangan). Data hasil penelitian kemampuan menulis teks cerpen sebagaimana tabel berikut ini.

Tabel 1. Data Kemampuan Menulis Teks Cerpen Mahasiswa Semester 5C Prodi S-1

Pendidikan Bahasa Indonesia FKIP Universitas Bengkulu, Tahun 2019/2020

\begin{tabular}{clccc}
\hline No. & \multicolumn{1}{c}{ Aspek } & Rerata & $\begin{array}{c}\text { Sumbangan } \\
\mathbf{( \% )}\end{array}$ & Kategori \\
\hline 1 & Kesesuaian judul dengan Isi & 16,45 & 20,14 & Baik \\
\hline 2 & Stuktur Teks & 23,9 & 29,26 & Baik \\
\hline 3 & Diksi atau Pilihan Kata & 16,18 & 19,81 & Baik \\
\hline 4 & Penggunaan Kalimat Naratif & 17,42 & 21,33 & Baik \\
\hline 5 & Mekanik (ejaan dan tulisan tangan) & 7,73 & 9,46 & Baik \\
\hline & Kemampuan Menulis Teks Cerpen (33 org) & $\mathbf{8 1 , 6 8}$ & $\mathbf{1 0 0}$ & Baik \\
\hline
\end{tabular}

Silampari Bisa: Jurnal Penelitian Pendidikan Bahasa Indonesia, Daerah, dan Asing 
Agus Joko Purwadi, Didi Yulistio

Kemampuan Menulis Teks Cerpen Mahasiswa Program Sarjana Pendidikan Bahasa Indonesia

Berdasarkan tabel data di atas, bahwa kemampuan menulis teks cerita pendek mahasiswa memperoleh rerata sebesar 81,68 berkategori baik. Pencapaian kemampuan menulis teks cerpen ini didasarkan pada 5 (lima) komponen, mencakup: (1) isi; kesesuaian pengembangan isi dengan tema dengan rata-rata skor sebesar 16,45 termasuk kategori baik $(20,14 \%)$, (2) struktur teks; meliputi orientasi, komplikasi, dan resolusi dengan rerata sebesar 23,9 termasuk berkategori baik $(29,26 \%)$, (3) diksi atau pilihan kata dengan rerata sebesar 16,18 berkategori baik $(19,81 \%)$, (4) penggunaan kalimat (gaya bahasa cerita) dengan rerata skor sebesar 17,42 berkategori sangat baik $(21,33 \%)$, dan (5) mekanik (ejaan dan tulisan tangan) dengan rata-rata skor sebesar 7,73 atau berada pada rentangan $7-8$, termasuk berkategori baik $(9,46 \%)$.

Hal tersebut bermakna bahwa dari kelima aspek kemampuan menulis teks cerita pendek sudah dikuasai secara baik. Walaupun belum mencapai skor maksimal dengan ketegori sangat baik dari masing-masing aspeknya. Sebab, hanya aspek penggunaan kalimat bergaya bahasa naratif yang mencapai tingkat kemampuan maksimal berkategori sangat baik. Artinya pencapaian kemampuan mahasiswa dalam menulis teks cerita pendek pada aspek yang lainnya perlu dipertahankan dan bahkan lebih ditingkatkan lagi untuk masa yang akan datang agar lebih baik lagi atau mencapai tingkat kemampuan yang maksimal. Berdasarkan besaran sumbangan masing-masing aspek dapat dilihat pada diagram batang berikut ini.

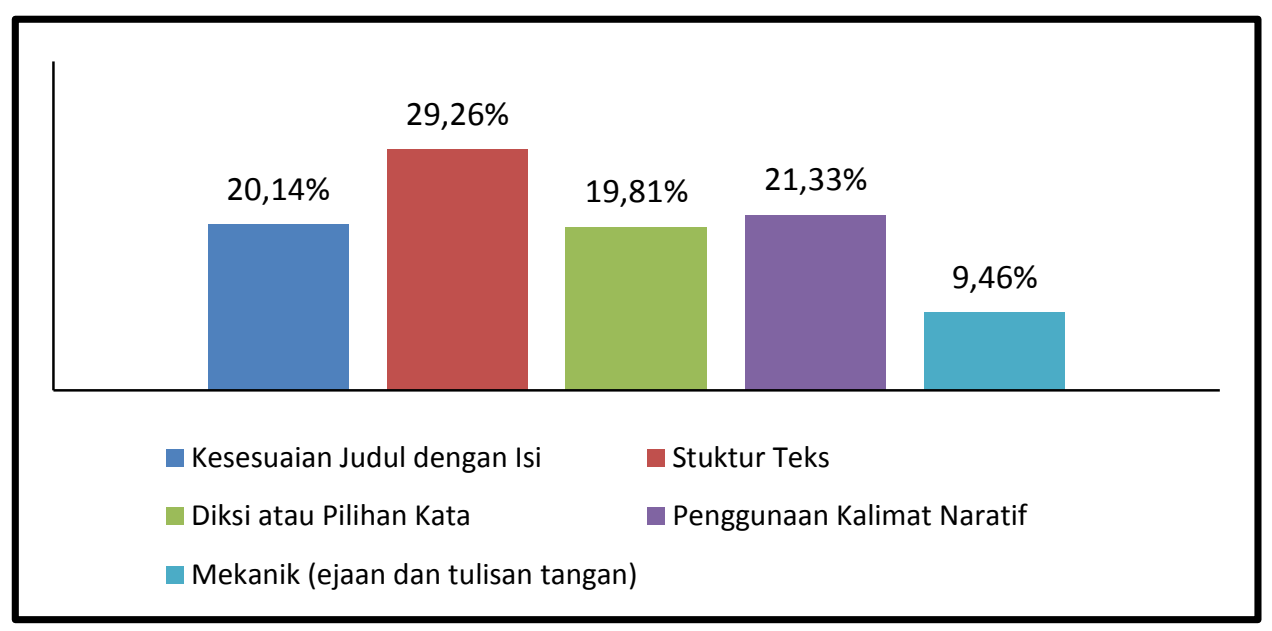

Diagram 1. Tingkat Pencapaian Kemampuan Menulis Teks Cerita Pendek Mahasiswa Berdasarkan Persentase Setiap Aspeknya

Pencapaian kemampuan menulis teks cerita mahasiswa dalam kategori baik yang didasarkan pada lima aspek telah memberikan sumbangan yang bervariasi sesuai bobot masing-masing aspeknya, yakni (1) aspek kesesuaian isi memberikan sumbangan sebesar 20,14\%, (2) struktur teks memberikan sumbangan sebesar 29,26\%, (3) pilihan kata memberikan sumbangan sebesar 19,81\%, (4) penggunaan kalimat bergaya bahasa naratif memberikan sumbangan sebesar $21,33 \%$, dan (5) mekanik atau ejaan memberikan sumbangan sebesar 9,46\%. Berdasarkan deskripsi frekuensi dan ketegori pilihan jawaban dikelompokkan menurut persentase sebagaimana tabel berikut ini. 
Agus Joko Purwadi, Didi Yulistio

Kemampuan Menulis Teks Cerpen Mahasiswa Program Sarjana Pendidikan Bahasa Indonesia

Tabel 2. Data Persentase Kemampuan Menulis Teks Cerita Pendek Mahasiswa

Prodi S-1 Pendidikan Bahasa Indonesia FKIP Universitas Bengkulu

Semester Ganjil 2019/2020

\begin{tabular}{clcc}
\hline No. & \multicolumn{1}{c}{ Kategori } & Frekuensi (f) & Persentase (\%) \\
\hline 1 & Sangat Baik & 10 & 30,3 \\
\hline 2 & Baik & 23 & 69,7 \\
\hline 3 & Cukup & 0 & 0 \\
\hline 4 & Kurang & 0 & 0 \\
\hline 5 & Sangat Kurang & 0 & 0 \\
\hline \multicolumn{2}{l}{ Total } & 33 & 100 \\
\hline
\end{tabular}

Deskripsi persentase frekuensi menurut tabel di atas, bahwa (a) sebanyak 10 orang mendapat skor berkategori sangat baik (sebanyak 30,3\%), dan (b) sebanyak 23 orang mendapatkan skor berkategori baik (sebanyak 69,7\%), sedangkan yang mendapatkan skor dengan kategori kurang dan sangat kurang, tidak ada. Berdasarkan frekuensi di atas dapat dideskripsikan diagram batang berikut ini.

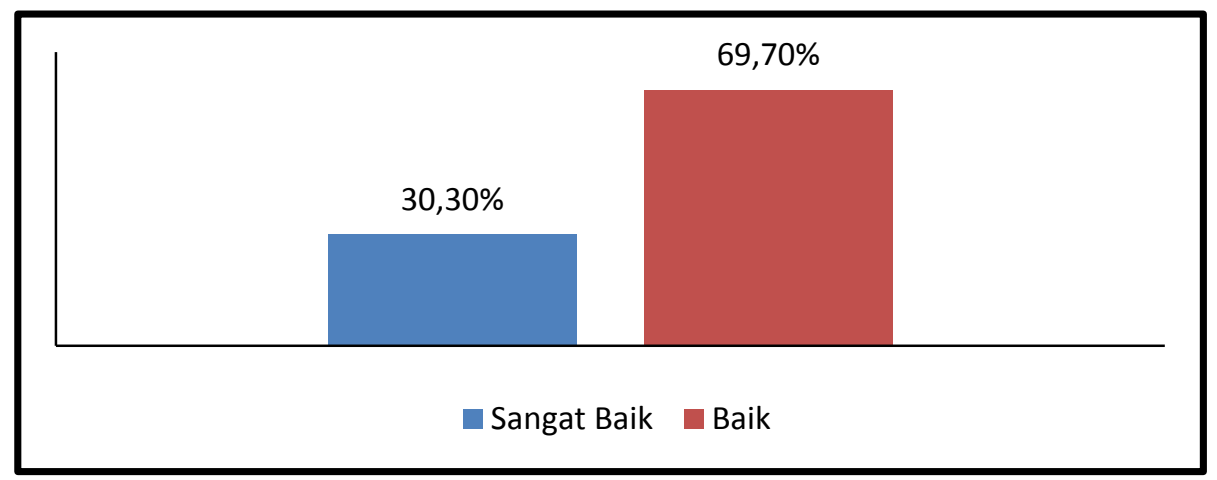

Diagram 2. Pencapaian Kemampuan Menulis Teks Cerita Pendek Mahasiswa Berdasarkan Persentase Frekuensi dan Kategorinya

Capaian di atas menunjukkan bahwa kemampuan menulis teks cerita pendek mahasiswa Prodi S-1 Pendidikan Bahasa Indonesia FKIP Universitas Bengkulu sudah dikuasai secara baik walaupun belum maksimal. Hal ini terlihat dari penguasaan semua aspek yang hampir merata atau hanya berkategori baik. Artinya, masih memerlukan latihan yang rutin agar mampu menguasai semua aspek secara lebih baik atau maksimal. Deskripsi di atas menunjukkan bahwa belum semua mahasiswa mendapat skor maksimal. Mahasiswa berkategori sangat baik sebanyak 30,3\% (10 orang), dan kategori baik sebanyak 69.7 (23 orang) Dengan demikian, masih diperlukan latihan yang rutin untuk meningkatkan kemampuan menulis teks cerpen mahasiswa secara maksimal.

Hasil kemampuan menulis cerpen secara khusus, setiap komponen/aspek yang mencakup isi, struktur teks, diksi, kalimat bergaya naratif, dan mekanik dapat dikemukakan pada bagian berikut ini. Deskripsi hasil kemampuan menulis teks cerita pendek aspek isi mahasiswa, bahwa pengembangan aspek isi tulisan terhadap tema "Kehidupan Kampus" dengan topik atau judul sesuai pilihan penulisnya mencapai kualitas rerata skor sebesar 16,45 termasuk berkategori baik. Artinya, pada penguasaan aspek isi mahasiswa sudah berkualifikasi baik walaupun belum maksimal atau belum mencapai skor tertinggi dengan rata-rata sebesar 20 (kategori sangat baik). Secara spesifik capaian

Silampari Bisa: Jurnal Penelitian Pendidikan Bahasa Indonesia, Daerah, dan Asing Vol. 4, No. 1, June 2021 
Agus Joko Purwadi, Didi Yulistio

Kemampuan Menulis Teks Cerpen Mahasiswa Program Sarjana Pendidikan Bahasa Indonesia

kualitas aspek isi dapat dilihat dari persentase frekuensi dan kategori pada tabel berikut ini.

Tabel 3. Persentase Frekuensi dan Kategori Kemampuan Menulis Teks Cerpen Mahasiswa Menurut Aspek Isi

\begin{tabular}{cclcc}
\hline No. & Skor & \multicolumn{1}{c}{ Kategori } & Frekuensi (f) & $\begin{array}{c}\text { Persentase } \\
\text { (\%) }\end{array}$ \\
\hline 1 & $17-20$ & Sangat Baik & 15 & 45,45 \\
\hline 2 & $13-16$ & Baik & 18 & 54,55 \\
\hline 3 & $9-12$ & Cukup & 0 & 0 \\
\hline 4 & $5-8$ & Kurang & 0 & 0 \\
\hline 5 & $1-4$ & Sangat Kurang & 0 & 0 \\
\hline & & Total & 33 & 100 \\
\hline
\end{tabular}

Berdasarkan data persentase frekuensi pada tabel di atas, bahwa (a) sebanyak 15 orang mendapat skor dalam rentangan $27-20$ berkategori sangat baik (45,45\%), (b) sebanyak 18 orang mendapatkan skor pada rentangan 13-16 termasuk berkategori baik $(54,55 \%)$, sedangkan yang mendapatkan skor pada rentangan 9-12, 5-8, dan 1-4 yang berkategori cukup, kurang, dan sangat kurang, tidak ada. Berdasarkan persentase frekuensi di atas dapat digambarkan dalam diagram batang berikut ini.

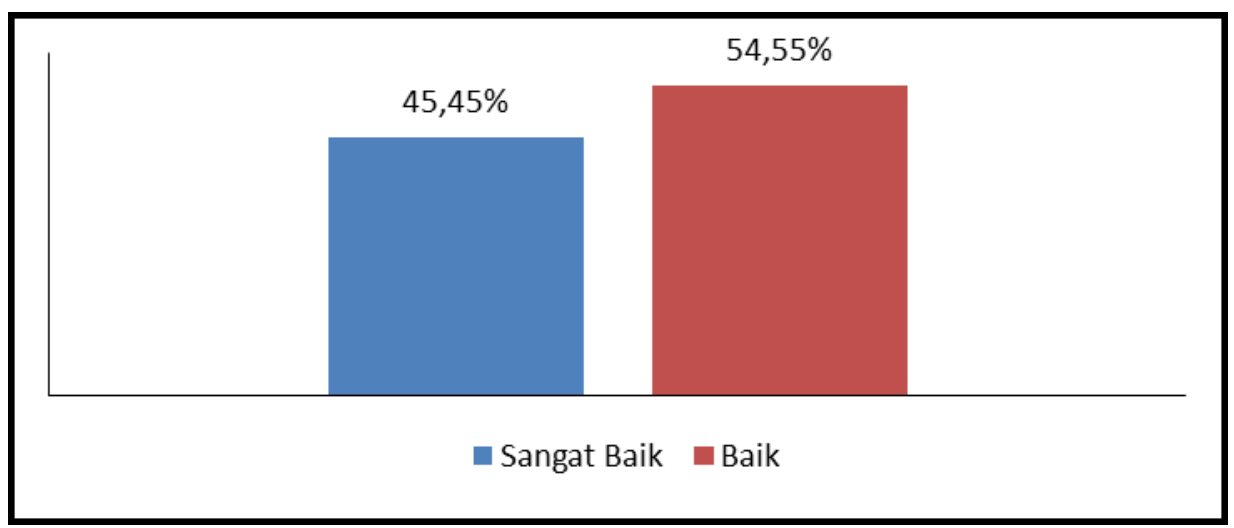

Diagram 3. Pencapaian Persentase Kategori Kemampuan

Menulis Teks Cerpen Aspek Isi

Capaian di atas menunjukkan bahwa kemampuan menulis teks cerpen aspek isi sudah dikuasai secara baik oleh mahasiswa walaupun belum maksimal atau belum mencapai skor rata-rata tertinggi sebesar 20 dalam kategori sangat baik.

Deskripsi hasil penilaian aspek struktur cerita yang meliputi orientasi, komplikasi, dan resolusi, mencapai skor rata-rata sebesar 23,9 berkategori baik. Artinya, pada aspek struktur ini penguasaan mahasiswa sudah baik tetapi belum berada pada kualitas maksimal (kategori sangat baik). Secara lebih spesifik capaian kualitas aspek struktur ini dapat dilihat pada tabel persentase frekuensi dan kategori berikut ini.

Tabel 4. Persentase Frekuensi dan Kategori Kemampuan Menulis Teks Cerpen Mahasiswa Menurut Aspek Struktur Teks

\begin{tabular}{cclcc}
\hline No. & Skor & \multicolumn{1}{c}{ Kategori } & Frekuensi (f) & Persentase (\%) \\
\hline 1 & $25-30$ & Sangat Baik & 11 & 33,33 \\
\hline 2 & $19-24$ & Baik & 22 & 66,67 \\
\hline 3 & $13-18$ & Cukup & 0 & 0 \\
\hline 4 & $7-12$ & Kurang & 0 & 0 \\
\hline 5 & $1-6$ & Sangat Kurang & 0 & 0 \\
\hline & Total & 33 & 100 \\
\hline
\end{tabular}

Silampari Bisa: Jurnal Penelitian Pendidikan Bahasa Indonesia, Daerah, dan Asing Vol. 4, No. 1, June 2021 
Agus Joko Purwadi, Didi Yulistio

Kemampuan Menulis Teks Cerpen Mahasiswa Program Sarjana Pendidikan Bahasa Indonesia

Kategori kemampuan mahasiswa dalam menulis teks cerpen aspek struktur diperoleh (a) sebanyak 11 orang mendapat skor dalam rentangan 25-30 berkategori sangat baik (sebesar 33,33\%), dan (b) sebanyak 22 orang mendapatkan skor dalam rentangan 19-24 termasuk berkategori baik (sebesar 66,67\%), sedangkan selebihnya tidak ada. Hal tersebut menunjukkan bahwa kemampuan aspek struktur sudah mencapai rerata kategori baik, tetapi memerlukan latihan rutin agar mencapai ketegori maksimal. Berdasarkan persentase frekuensi di atas dapat digambarkan dalam diagram batang berikut ini.

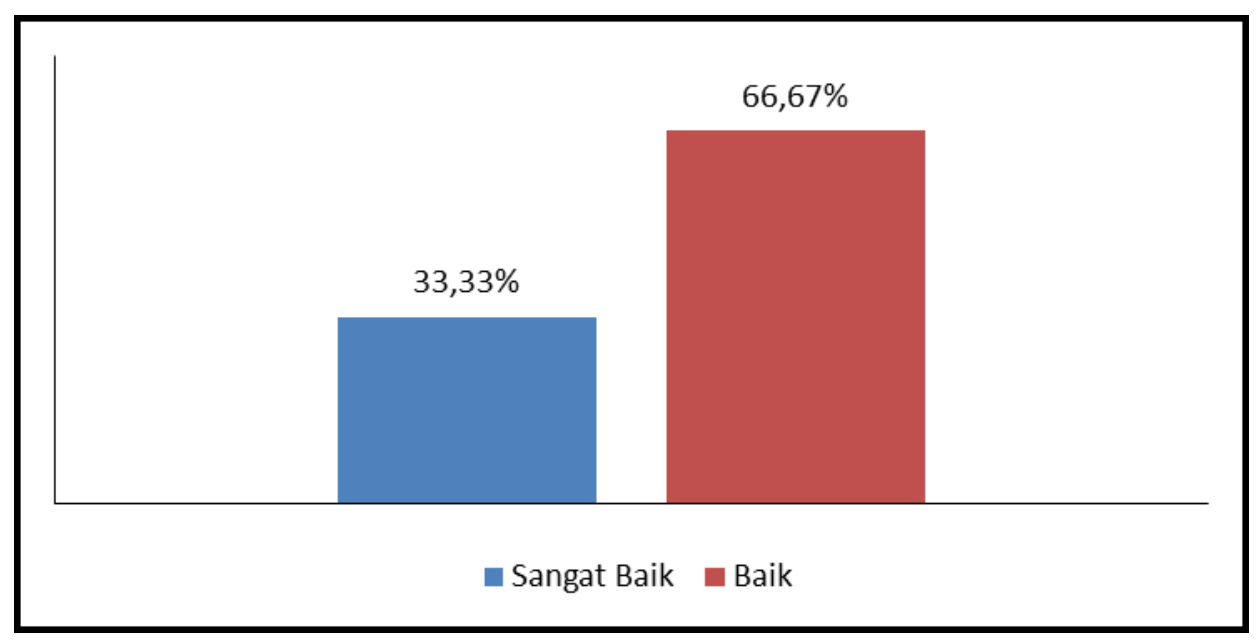

Diagram 4. Pencapaian Persentase Kategori Kemampuan Menulis Teks Cerita Mahasiswa Berdasarkan Aspek Struktur

Capaian di atas menunjukkan bahwa kemampuan menulis teks cerpen aspek struktur sudah dikuasai secara baik oleh mahasiswa walaupun belum mencapai skor ratarata tertinggi sebesar 30 . Hal ini terlihat dari penguasaan aspek struktur berkategori sangat baik sebanyak 11 orang (sebesar 33,33\%) dan kategori baik sebanyak 22 orang (sebesar $66,67 \%$ ) sedangkan selebihnya, tidak ada.

Deskripsi hasil penilaian aspek diksi/pilihan kata dalam teks cerpen mahasiswa mencapai skor rata-rata sebesar 16,18 (berada dalam rentangan 13-16) berkategori baik. Artinya, pada aspek ini penguasaan mahasiswa sudah berada pada kualitas baik walaupun belum maksimal. Karena, belum mencapai skor tertinggi dengan rata-rata sebesar 20 kategori sangat baik. Secara lebih spesifik capaian kualitas aspek pilihan kata ini dapat diperhatikan pada tabel persentase frekuensi dan kategori berikut ini.

Tabel 5. Persentase Frekuensi dan Kategori Kemampuan Menulis Teks Cerpen Mahasiswa Menurut Aspek Diksi (Pilihan Kata)

\begin{tabular}{cclcc}
\hline No. & Skor & \multicolumn{1}{c}{ Kategori } & Frekuensi (f) & Persentase (\%) \\
\hline 1 & $17-20$ & Sangat Baik & 11 & 33,33 \\
\hline 2 & $13-16$ & Baik & 22 & 66,67 \\
\hline 3 & $9-12$ & Cukup & 0 & 0 \\
\hline 4 & $5-8$ & Kurang & 0 & 0 \\
\hline 5 & $1-4$ & Sangat Kurang & 0 & 0 \\
\hline & Total & 33 & 100 \\
\hline
\end{tabular}

Silampari Bisa: Jurnal Penelitian Pendidikan Bahasa Indonesia, Daerah, dan Asing Vol. 4, No. 1, June 2021 
Agus Joko Purwadi, Didi Yulistio

Kemampuan Menulis Teks Cerpen Mahasiswa Program Sarjana Pendidikan Bahasa Indonesia

Dari data persentase frekuensi di atas, bahwa (a) sebanyak 11 orang mendapat skor dalam rentangan 17-20 berkategori sangat baik (sebesar 33,33\%), (b) sebanyak 22 orang mendapatkan skor dalam rentangan 13-16 termasuk berkategori baik (sebesar $66,67 \%$ ), sedangkan selebihnya dalam kategori cukup, kurang, dan sangat kurang tidak ada. Data persentase frekuensi di atas dapat digambarkan dalam diagram batang berikut ini.

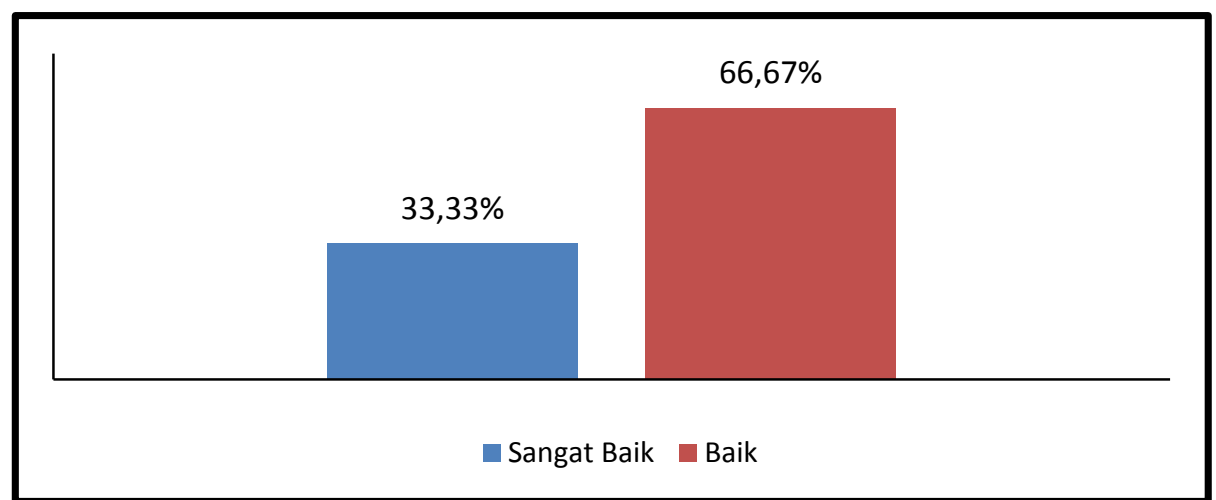

Diagram 5. Pencapaian Persentase Kategori Kemampuan Menulis Teks Cerpen Mahasiswa Berdasarkan Aspek Diksi (Pilihan Kata)

Capaian di atas menunjukkan bahwa kemampuan menulis teks cerita pendek pada aspek pilihan kata sudah dikuasai secara baik walaupun belum mencapai skor maksimal. $\mathrm{Hal}$ ini terlihat dari penguasaan mahasiswa pada kategori sangat baik sebanyak 11 orang (sebesar 33,33\%), berkategori baik sebanyak 22 orang (sebesar 66,67\%), dan seelebihnya kategori cukup, kurang, dan sangat kurang, tidak ada.

Deskripsi hasil penilaian aspek penggunaan kalimat naratif dalam menulis teks cerpen mencapai skor rerata $\mathbf{1 7 , 4 2}$ berkategori sangat baik. Artinya, pada aspek penggunaan kalimat bergaya bahasa naratif ini, penguasaan mahasiswa sudah berada pada kualitas maksimal. Secara spesifik capaian kualitas aspek penggunaan kalimat bergaya bahasa naratif ini dapat dilihat pada tabel berikut ini.

Tabel 6. Persentase Frekuensi dan Kategori Kemampuan Menulis Teks Cerpen Mahasiswa Menurut Aspek Penggunaan Kalimat Bergaya Bahasa Naratif

\begin{tabular}{cclcc}
\hline No. & Skor & \multicolumn{1}{c}{ Kategori } & Frekuensi (f) & Persentase (\%) \\
\hline 1 & $17-20$ & Sangat Baik & 24 & 72,73 \\
\hline 2 & $13-16$ & Baik & 9 & 27,27 \\
\hline 3 & $9-12$ & Cukup & 0 & 0 \\
\hline 4 & $5-8$ & Kurang & 0 & 0 \\
\hline 5 & $1-4$ & Sangat Kurang & 0 & 0 \\
\hline & Total & 33 & 100 \\
\hline
\end{tabular}

Data frekuensi di atas menunjukkan bahwa (a) mahasiswa yang mendapat kategori sangat baik sebanyak 24 orang dan (b) mahasiswa yang mendapat skor dalam rentangan 13-16 termasuk berkategori baik sebanyak 9 orang serta selebihnya yang mendapat skor dalam kategori cukup, kurang, dan sangat kurang, tidak ada. Data persentase frekuensi di atas dapat digambarkan dalam diagram batang berikut ini. 


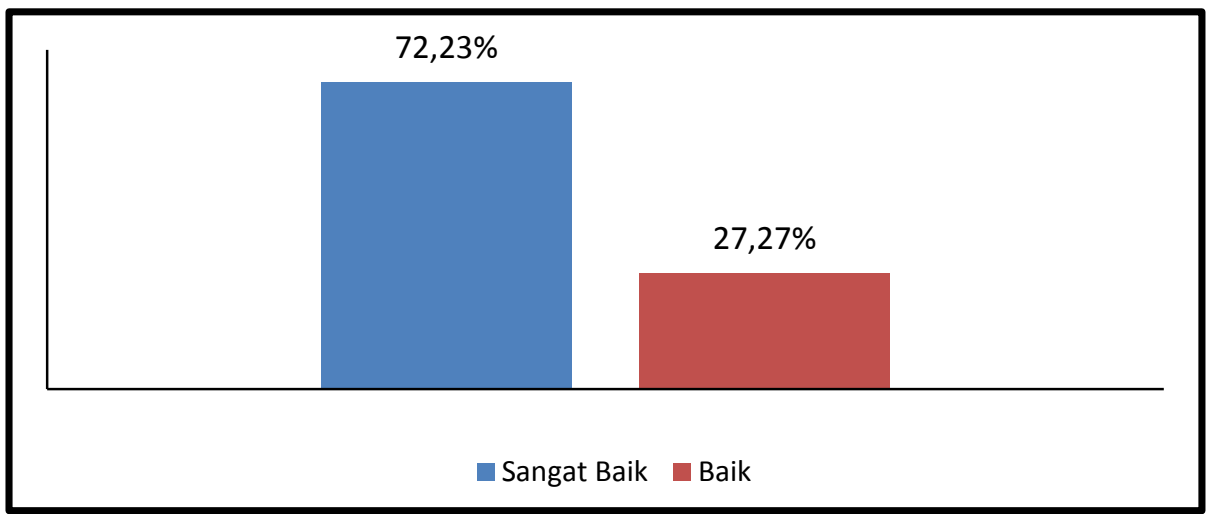

Diagram 6. Pencapaian Persentase Kategori Kemampuan Menulis Teks Cerpen Mahasiswa Berdasarkan Aspek Penggunaan Kalimat Gaya Bahasa Naratif

Gambaran capaian pada diagram di atas menunjukkan bahwa kemampuan menulis teks cerita pendek pada aspek penggunaan kalimat bergaya bahasa sudah dikuasai secara sangat baik oleh mahasiswa walaupun belum semuannya mencapai skor maksimal. Hal ini terlihat dari pencapaian yang berkategori sangat baik sebanyak 24 orang (sebesar 72,73\%) dan yang berkategori baik sebanyak 9 orang (sebesar 27,27\%) sedangkan selebihnya yang berkategori cukup, kurang, dan sangat kurang, tidak ada.

Berdasarkan deskripsi hasil aspek mekanik atau ejaan dan tulisan tangan diperoleh skor rata-rata sebesar 7,73 berkategori baik. Artinya, pada aspek ini penguasaan mahasiswa belum berada pada kualitas maksimal. Oleh karena itu, perlu upaya untuk meningkatkan pencapaian aspek mekanik agar mencapai hasil maksimal. Secara spesifik capaian kualitas aspek mekanik ini dapat dilihat pada tabel presentase frekuensi dan kategori berikut ini.

Tabel 7. Persentase Frekuensi dan Kategori Kemampuan Menulis Teks Cerpen Mahasiswa Menurut Aspek Mekanik (Ejaan dan Tulisan Tangan)

\begin{tabular}{|c|c|c|c|c|}
\hline No. & Skor & Kategori & Frekuensi (f) & Persentase (\%) \\
\hline 1 & $9-10$ & Sangat Baik & 5 & 15,15 \\
\hline 2 & $7-8$ & Baik & 28 & 84,85 \\
\hline 3 & $5-6$ & Cukup & 0 & 0 \\
\hline 4 & $3-4$ & Kurang & 0 & 0 \\
\hline \multirow[t]{2}{*}{5} & $1-2$ & Sangat Kurang & 0 & 0 \\
\hline & & Total & 33 & 100 \\
\hline
\end{tabular}

Data frekuensi di atas, menunjukkan bahwa terdapat (a) mahasiswa yang mendapat skor dalam rentangan 9-10 berkategori sangat baik sebanyak 5 orang, (b) mencapai rentangan skor 7-8 termasuk kategori baik sebanyak 28 orang, dan selebihnya yang mendapkan skor dalam kategori cukup, kurang dan sangat kurang, tidak ada. Besaran Persentase frekuensi di atas dapat digambarkan dalam diagram batang berikut ini. 


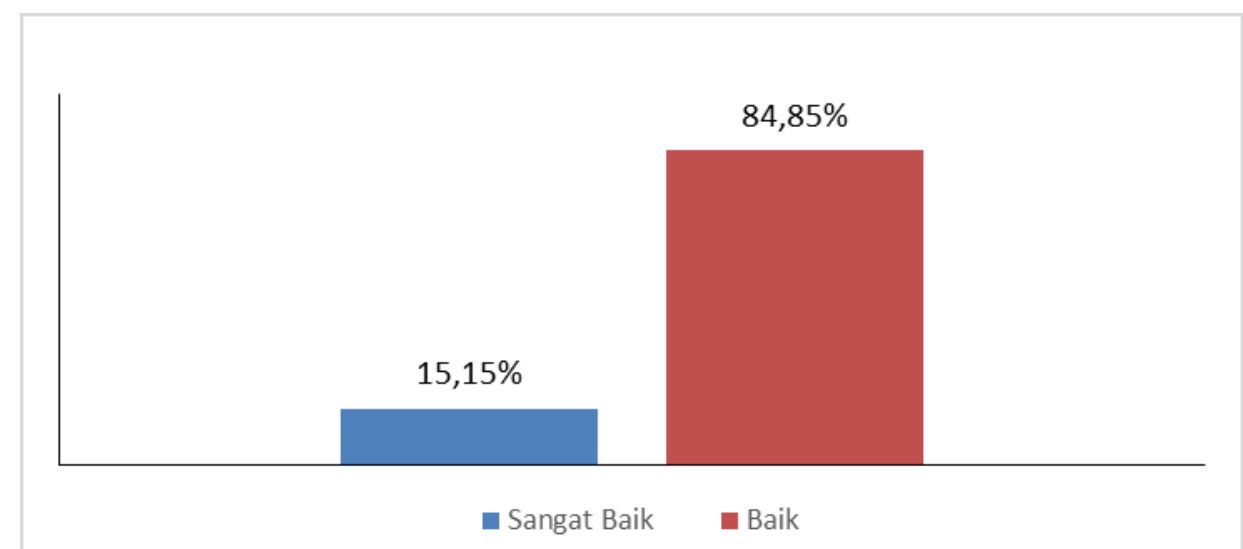

Diagram 7. Pencapaian Persentase Kategori Kemampuan Menulis Teks Cerpen Mahasiswa berdasarkan Aspek Mekanik

Gambaran capaian pada diagram di atas menunjukkan bahwa kemampuan menulis teks cerita aspek mekanik (ejaan dan tulisan tangan) sudah dikuasai secara baik oleh mahasiswa walaupun belum semuannya mencapai rata-rata skor tertinggi sebesar 10 . Hal ini terlihat dari penguasaan yang berkategori sangat baik sebesar 15,15\% (sebanyak 5 orang) dan berkategori baik sebesar $84,85 \%$ (sebanyak 28 orang) serta yang mencapai kategori cukup, kurang, dan sangat kurang, tidak ada.

\section{Pembahasan}

Berdasarkan hasil kemampuan menulis teks cerpen mahasiswa Program Studi S-1 Pendidikan Bahasa Indonesia FKIP Universitas Bengkulu yang berkategori baik (rerata $81,68)$, maka secara umum telah memiliki kemampuan dalam menulis cerpen. Hasil ini didasarkan pada rerata empat aspek kemampuan menulis teks cerpen yang berkategori baik dan satu aspek berkategori sangat baik. Adapun sumbangan setiap aspek terhadap kemampuan menulis teks cerpen, bahwa (1) kesesuaian isi (rerata sebesar 16,45) memberikan sumbangan 20,14\%, (b) struktur teks cerpen (rerata skor 23,9) memberikan sumbangan 29,26\%, (c) diksi atau pilihan kata (rerata skor 16,18) memberikan sumbangan 19,81\%, (d) kalimat gaya bahasa naratif (rerata skor 17,42) memberikan sumbangan $21,33 \%$, dan aspek (e) mekanik atau ejaan dan tulisan tangan (rerata skor 7,73 ) memberikan sumbangan $9,46 \%$.

Hasil ini menunjukkan bahwa mahasiswa Program Studi S-1 Pendidikan Bahasa Indonesia FKIP Universitas Bengkulu, semester ganjil 2019/2020 sudah memiliki kualitas yang memadai dalam menulis teks cerita pendek tersebut. Hal ini sesuai dengan pendapat Rivers (dalam Hadley, 1993: 290-292) yang mengemukakan bahwa kemampuan menulis merupakan kecakapan seseorang dalam menggunakan unsur kebahasaan dan struktur teks tulisan dengan memanfaatkan konteks nyata. Dengan kata lain, sesuai pencapaian setiap aspeknya, bahwa mahasiswa sudah dapat mengembangkan gagasan tulisan (tema) yang diwujudkan menjadi judul dan isi tulisan dalam rangkaian kalimat dan paragraf atau teks cerita pendek yang bermakna. Namun, capaian tersebut belum maksimal sehingga perlu terus dikembangkan pada semua aspek yakni pengembangan isi, struktur, diksi, dan mekanik (ejaan dan tulisan tangan) agar lebih baik lagi sedangkan pada aspek kalimat bergaya bahasa naratif telah mencapai kategori sangat baik. Hal ini sesuai dengan pemikiran Wiratno (2014) bahwa mahasiswa perlu dilatih secara terus-menerus dalam mewujudkan tulisan atau menulis teks melalui membangun konteks, pemodelan teks, kerja sama membangun teks, dan kerja mandiri dalam mewujudkan teks yang baik hingga memiliki kecakapan dalam mengembangkan teks secara mandiri benar-benar berkarakter. 
Pencapaian kemampuan menulis teks cerita pendek aspek isi atau pengembangan tema tulisan menjadi uraian isi tulisan, bahwa mahasiswa sudah mencapai hasil yang baik, tetapi belum maksimal atau masih perlu mencapai nilai berkategori sangat baik. Oleh karena itu, pada aspek isi ini masih memerlukan latihan rutin dengan mengontrol kedisiplinan dan kepekaan dalam memahami tema atau topik sehingga menjadi judul dan isi tulisan yang lengkap dan akurat. Mahasiswa sebenarnya sudah mampu menguraikan dan mengembangkan tema tulisan "Kehidupan Kampus" menjadi berbagai judul sesuai pengembangan isi tulisan yang dibuatnya walaupun hasilnya belum mencapai skor maksimal. Hal ini sesuai dengan pendapat Byrne (dalam Yulistio, 2012: 25), bahwa kemampuan menulis merupakan upaya seseorang dalam mewujudkan dan kolektivitas pengetahuan kebahasaan dan pengolahan gagasan (ide-ide) melalui pikiran menjadi kalimat-kalimat dan paragraf yang bermakna (mengembangkan tema menjadi judul dan isi tulisan). Pengembangan paragraf yang berhasil dapat direfleksikan pembaca dalam memahami isi tulisan secara mudah dan berhasil.

Begitu pula pada aspek struktur teks yang mengembangkan unsur orientasi, komplikasi, dan resolusi sudah diwujudkan oleh mahasiswa secara baik walaupun belum mencapai hasil yang maksimal. Ketiga unsur pengembangan struktur cerita sudah tampak membedakan dari isinya. Pengembangan struktur orientasi perlu pengenalan situasi, lokasi, dan isi cerita dari para tokohnya. Pada unsur komplikasi masih perlu pengembangan munculnya masalah tikaian cerita. Sedangkan pada unsur resolusi cenderung belum maksimal khususnya dalam mengakhiri isi cerita bahkan masih ditemukan cerita yang tidak diakhiri dengan bagian resolusi yang tepat karena akhir komplikasi dirasakan penulisnya sebagai akhir cerita. Bagian resolusi ini perlu disusun dengan uraian yang lebih jelas, lebih spesifik, dan lebih menonjolkan pikiran dan gagasan penyelesaian akhir atau cara menyelesaikan permasalahannya. Hal ini sebagaimana ditegaskan Kementerian Pendidikan dan Kebudayaan RI (2013: 3), bahwa penempatan struktur teks cerita yang baik akan membentuk urutan organisasi pola berpikir yang baik secara berurutan sehingga setiap pengembangan unsur struktur cerita akan memperlihatkan keruntutan pola berpikir yang jelas terhadap alur dan isi cerita yang ditulis.

Pada pencapaian kemampuan menulis teks cerita aspek diksi atau pilihan kata, bahwa mahasiswa sudah mendapatkan kualitas yang baik. Hanya saja perlu penguatan dalam hal pemilihan kata yang sesuai tema atau topik yang ada. Masih terjadi kesalahan pilihan kata yang tidak sesuai dengan topik atau judul tulisan. Pilihan kata tidak tepat atau tidak relevan dengan temanya secara tersirat, seperti ketika penulis mengawali kalimat dalam paragraf yang berunsur komplikasi dengan kata-kata seorang ibu yang bertanya "mengapa kamu tak mau sekolah nak?" dan jawaban si anak "saya mau membantu ibu saja." Hal tersebut bukan pengembangan isi yang baik dan rasional. Sebab, jika seorang anak akan membantu orang tuannya bukan saat itu, tetapi ketika sudah mampu (dewasa) nanti dan ketika itu bukan saatnya membantu orang tua dengan bekerja teapi secara rasonal harusnya ketika masih anak-anak harus belajar atau sekolah. Karena, dengan belajar yang berhasil nanti akan mendapatkan pengalaman untuk bekerja secara baik ketika sudah dewasa sebagai bentuk makna tersirat 'menopang ekonomi keluarga' untuk membantu orang tua. Di samping itu, banyak pilihan kata yang tidak relevan dengan temanya, seperti kata-kata 'Ibu yang sudah tua telah diambil nyawanya oleh yang Maha Kuasa' perlu diganti dengan kata "Ibu yang dalam kondisi sakit-sakit itu telah tiada atau meninggal dunia." Pemilihan kata mubajir juga masih terjadi seperti penggunaan kata "jalan raya besa" di depan rumahku. Seharunya, digunakan diksi "jalan raya" atau "jalan besar" saja.

Silampari Bisa: Jurnal Penelitian Pendidikan Bahasa Indonesia, Daerah, dan Asing Vol. 4, No. 1, June 2021 
Pada pencapaian kemampuan menulis teks cerpen aspek penggunaan kalimat bergaya bahasa, bahwa mahasiswa sudah sangat efektif dalam menggunakannya sehingga kalimat yang berimajinatif mampu membawa pembacara ikutserta berada dalam suasana cerita. Kalimat pembuka teks cerita ini bergaya nonformal dan menunjukkan kesan bergaya bahasa yang indah dan menarik pembaca karena sebuah cerita, misalnya dari judul "Kampusku" pada kalimat pertama paragraf orientasi digunakan kalimat yang menggambarkan situasi seperti "Pagi itu, pagi yang paling bersejarah dalam hidupku" dibuat bernilai deskripsi atau naratif sehingga bergaya bahasa cerita. Karena dari segi maknanya, kalimat tersebut telah menggambarkan keadaan dalam setiap hari tentu banyak keluarga mengalami hal seperti itu. Oleh karena itu, orientasi perlu menggambarkan keadaan kejiwan tokoh penceritanya. Sehingga kalimat tersebut menarik pembaca untuk menelusuri isi ceritanya, ada apa dan mengapa dengan keadaan tokoh ini.

Pada pencapaian kemampuan menulis teks cerita aspek mekanik khususnya ejaan masih terjadi kesalahan namun tidak fatal. Seperti penulisan kata "adalah" yang tidak dipergunakan untuk menjelaskan konsep atau definisi, seperti kalimat "aku adalah anak ke 2 dari lima bersaudara...", perlu dihindari dan penulisan "ke 2" yang benar langsung ditulis dengan kata "kedua.". Penulisan kata partikel "ku" dalam "ku sampaikan" seharusnya ditulis serangkai menjadi "kusampaikan.". Beberapa kata yang berkaitan dengan lafal kedaerahan atau pengaruh bahasa ibu memunculkan bahasa yang salah ketika ditulis seperti "ke rumah" ditulis "keruma" seharusnya menurut ejaan bahasa Indonesia kata tersebut ditulis terpisah karena menggunakan kata depan 'ke' dan 'rumah' sehingga bentuk yang benar 'ke rumah' bukan ditulis kerumah' atau 'keruma.' Beberapa penggunaan bentuk tanda baca masih perlu mendapat perhatian dan perlu memahami aturan EBI (sebagaimana telah diatur dalam Peraturan Menteri Pendidikan dan Kebudayaan Republik Indonesia Nomor 50, tahun 2015).

Adanya kekurangtepatan dalam mengembangkan isi, struktur cerita, dan ketepatan pilihan kata serta ejaan dalam menulis teks cerita di atas dapat diatasi dengan memperbanyak latihan penggunaan aspek kebahasaan, seperti ejaan bahasa Indonesia dan tata bahasa baku bahasa Indonesia. Sebagaimana ditegaskan Perkins (dalam Hadley, 1993: 343-345) bahwa kecermatan dalam menilai teks perlu didasarkan pada penilaian analitik tulisan, mencakup struktur, isi, diksi, kalimat, dan mekanik atau ejaan dan bahkan makna sesuai konteksnya. Khusus pada aspek penggunaan kalimat bergaya bahasa naratif sudah sesuai dengan kebutuhan teks yang disusun yakni teks cerita pendek. Teks ini memerlukan penggambaran situasi, kondisi, dengan imajinasi konteks yang lebih luas.

\section{Simpulan}

Berdasarkan hasil penelitian dan pembahasan dapat disimpulkan bahwa kemampuan menulis teks cerpen mahasiswa Prodi S-1 Pendidikan Bahasa Indonesia FKIP Universitas Bengkulu semester ganjil 2019/2020 telah mencapai kategori baik. Artinya, dari kelima aspek, bahwa empat aspek pembangun teks cerpen ini perlu dipertahankan dan ditingkatkan secara kualitas, khususnya aspek isi, struktur, diksi, dan mekanik agar menjadi lebih baik lagi, sedangkan aspek kalimat bergaya naratif sudah mencapai hasil maksimal atau berkategori sangat baik. Pencapaian kemampuan menulis teks cerpen secara maksimal dapat dilakukan melalui latihan dalam perkuliahan menulis fiksional. Adapun sumbangan setiap aspek terhadap kemampuan menulis teks cerpen mahasiswa, bahwa aspek: (1) kesesuaian tema dengan isi memberikan sumbangan $20,14 \%$, (2) struktur teks memberikan sumbangan $29,26 \%$, (3) diksi memberikan sumbangan $19,81 \%$, (4) kalimat bergaya naratif memberikan sumbangan $21,33 \%$, dan 
Agus Joko Purwadi, Didi Yulistio

Kemampuan Menulis Teks Cerpen Mahasiswa Program Sarjana Pendidikan Bahasa Indonesia

(5) aspek mekanik memberikan sumbangan 9,46\%. Adapun, sumbangan tertinggi dicapai dari aspek struktur teks.

\section{Daftar Pustaka}

Bachman, L. F. (1990). Fundamental Considerations in Language Testing. Oxford: Oxford University Press.

Djiwandono, S. (2008). Tes Bahasa Pegangan Bagi Pengajar Bahasa. Jakarta: PT Indeks.

Hadley, A. O. (1993). Teaching Language in Context. Boston: Heinle \& Heinle Publishers.

Heaton, J.B. (1988). Writing English Language Tests. New York: Longman Group UK Limited.

Jacobs, H. L., et. al. (1981). Testing ESL Composition: A. Practical Approach. Massacheserttes: Newbury House Publishers, Inc.

Johnson, E. B. (2002). Contextual Teaching and Learning: What it is and Why it's Here to Stay. Callifornia: Corwin Press, Inc.

Kementerian Pendidikan dan Kebudayaan RI. (2013). Bahasa Indonesia: Wahana Pengetahuan untuk SMP/MTs Kelas VII. Buku Siswa. Jakarta: Kementerian Pendidikan dan Kebudayaan.

Kementerian Pendidikan dan Kebudayaan RI. (2014). Buku Guru: Bahasa Indonesia Wahana Pengetahuan untuk SMP/MTs Kelas VII. Jakarta: Kementerian Pendidikan dan Kebudayaan.

Latief, M. A. (2002). Pengembangan Bahan Ajar Kontekstual Bahasa Inggris SLTP Cawu 2 untuk 6 Provinsi di Kalimantan dan Sulawesi. Jurnal Penelitian Kependidikan, 12(1), Juni.

Noermanzah, N. N. (2017). Plot in a Collection of Short Stories "Sakinah Bersamamu" Works of Asma Nadia with Feminimism Analysis. Humanus, 16(1), 29. doi:10.24036/jh.v16i1.7015

Nur, M. (2001). "Pengajaran dan Pembelajaran Kontekstual", Makalah Pelatihan TOT Guru Mata Pelajaran SLTP dan MTs, Juni.

Nurgiyantoro, B. (2007). Teori Pengkajian Fiksi. Yogyakarta: Gadjah Mada University Press.

Peraturan Menteri Pendidikan dan Kebudayaan Republik Indonesia Nomor 50 Tahun 2015 tentang Pedoman Umum Ejaan Bahasa Indonesia.

Rampan, K. L. (1995). Dasar-Dasar Penulisan Cerita Pendek. Flores: Nusa Indah.

Silampari Bisa: Jurnal Penelitian Pendidikan Bahasa Indonesia, Daerah, dan Asing

Vol. 4, No. 1, June 2021 
Agus Joko Purwadi, Didi Yulistio

Kemampuan Menulis Teks Cerpen Mahasiswa Program Sarjana Pendidikan Bahasa Indonesia

Satori. (2013). "Komponen Kompetensi Profesional Guru", Pendidikanku: Informasi Pendidikan Terkini. http://sdnwonoue.blogspot.com/2013/08.html. Diunduh, 27 April 2015.

Sevilla, C. G., dkk. (1993). Pengantar Metode Penelitian. Terjemahan Alimuddin Tuwu. Jakarta: UI Press.

Sudjiman, P. (1990). Memahami Cerita Rekaan. Jakarta: Pustaka Jaya.

Tarigan, H. G. (2013). Menulis sebagai Suatu Keterampilan Berbahasa. Bandung: Angkasa.

Undang-Undang Republik Indonesia Nomor 14 Tahun 2005 tentang Guru dan Dosen.

Wiratno, T. (2014). "Pembelajaran Bahasa Indonesia berbasis Teks dalam Kurikulum 2013". Materi Pelatihan Instruktur Nasional Pembelajaran Bahasa Indonesia Berbasis Teks. Jakarta: Badan Pengembangan dan Pembinaan Bahasa.

Yulistio, D. (2012). "Pengaruh Strategi Pembelajaran dan Kemampuan Penalaran terhadap Keterampilan Menulis", Disertasi Tidak Diterbitkan. Jakarta: Universitas Negeri Jakarta.

Yulistio, D., \& Fhitri, A. (2019). Peningkatan Kemampuan Menulis Cerpen Menggunakan Model Pembelajaran Pedagogi Genre, Saintifik, dan CLIL (Content and Language Integrated Learning) pada Siswa Kelas XI SMAN 2 Kota Bengkulu. Jurnal IImiah KORPUS, 3(1), 9-20. doi:10.33369/jik.v3i1.7342

Zainurrahman. (2011). Menulis: Dari Teori Hingga Praktik (Penawar Racun Plagiarimse). Bandung: Alfabeta. 